\title{
mRNA expression of the severe acute respiratory syndrome-coronavirus 2 angiotensin-converting enzyme 2 receptor in the lung tissue of Wistar rats according to age
}

\author{
Hazem Almhanna1 ${ }^{(\mathbb{D}}$, Nabeel Abd Murad Al-Mamoori ${ }^{1}$ D and Hassan Hachim Naser ${ }^{2}$ D
}

1. Department of Anatomy, Histology and Embryology, College of Veterinary Medicine, University of Al-Qadisiyah, Al-Qadisiyah, Iraq; 2. Department of Microbiology, College of Veterinary Medicine, University of Al-Qadisiyah, Al-Qadisiyah, Iraq.

Corresponding author: Hazem Almhanna, e-mail: hazem.almhanna@qu.edu.iq

Co-authors: NAMA: nabeel.almamorri@qu.edu.iq, HHN: hassan.naser@qu.edu.iq

Received: 30-08-2021, Accepted: 12-01-2022, Published online: 24-02-2022

doi: www.doi.org/10.14202/vetworld.2022.427-434 How to cite this article: Almhanna H, Al-Mamoori NAM, Naser HH (2022) mRNA expression of the severe acute respiratory syndrome-coronavirus 2 angiotensin-converting enzyme 2 receptor in the lung tissue of Wistar rats according to age, Veterinary World, 15(2): 427-434.

\section{Abstract}

Background and Aim: Angiotensin-converting enzyme 2 (ACE2) is expressed and plays functional and physiological roles in different tissues of the body. This study aimed to distinguish the levels of expression of ACE2 in the lung tissue at different ages of rats.

\begin{abstract}
Materials and Methods: In this study, 18 male rats were used and divided into three groups according to age. Real-time quantitative polymerase chain reaction (RT-qPCR) was conducted to determine the levels of the quantification of eosinophil cationic protein mRNA transcript. In addition, tissue specimens of the lung were stained with routine hematoxylin and eosin stains.

Results: This study confirmed that RT-qPCR amplification plots of ACE2 gene exhibited clearly expression of the lung tissue of rats in the different groups and there are strong different threshold cycles numbers according to the age at 2 weeks, 2 months, and 6-8 months. Consequently, the expression of ACE2 was completely different between groups depending on the age of the rats. The RT-qPCR results showed that the older animal group (age of 6-8 months) had a significantly higher expression of ACE2 than the other animal groups (ages of 2 weeks and 2 months). In the same way, the second group (age of 2 months) had a significantly higher expression of ACE2 than the first group (age of 2 weeks). This study confirmed that the ACE2 expression is influenced by the age of rats.
\end{abstract}

Conclusion: This study concluded that the expression of the ACE2 receptor of coronavirus disease 2019 would be different according to the age of rats, and this result suggested that expression of ACE2 in lung tissue could determine infection and pathogenesis of COVID-19 during different ages of rats or some individual differences.

Keywords: angiotensin-converting enzyme 2, expression, rats, real-time polymerase chain reactions, severe acute respiratory syndrome coronavirus 2 .

\section{Introduction}

Angiotensin-converting enzyme 2 (ACE2) is an enzyme found in the cell membrane of different tissues of the body. Extensive research has identified ACE2 in the tissues of the intestine, heart, kidney, gallbladder, lung, and testis [1-5]. Structurally, ACE2 is a glycoprotein and has some similarities with the ACE [6]. ACE2 is considered a type I integral glycoprotein found in the cell membrane of most cells of the body and has six potential N-glycosylation sites [7]. In addition, it is a carboxypeptidase that cleaves a single hydrophobic/basic residue that extends from the C-terminus of its substrates [8].

Copyright: Almhanna, et al. Open Access. This article is distributed under the terms of the Creative Commons Attribution 4.0 International License (http://creativecommons.org/licenses/ by/4.0/), which permits unrestricted use, distribution, and reproduction in any medium, provided you give appropriate credit to the original author(s) and the source, provide a link to the Creative Commons license, and indicate if changes were made. The Creative Commons Public Domain Dedication waiver (http:// creativecommons.org/publicdomain/zero/1.0/) applies to the data made available in this article, unless otherwise stated.
The ACE2 is structurally considered vasoconstrictor and vasodilator peptide; therefore, it can be led to balance of the blood pressure of the body by regulating the heart and kidney functions $[9,10]$. Much evidence explained that ACE2 has a physiological and pathological influence on the renal, respiratory, and cardiovascular systems, such as acute respiratory distress syndrome [11].

More studies were noticed that using the ACE2 protects the kidneys of mice which were suffered experimentally diabetic nephropathy and mediated treatment pathway of the kidney injury. In addition, it is considered an important determinant of diabetic nephropathy $[12,13]$. It may regulate the effects and levels of angiotensin 2 in the kidneys [14] and regularly protect the heart and kidney functions [15]. Therefore, ACE2 is correlated with cardiac, vascular, and renal dysfunctions [16].

Importantly, severe acute respiratory syndrome coronavirus 2 (SARS-CoV-2) infection in cats and ferrets is related to the distribution of ACE2, a receptor found in the respiratory system, including the 
lung tissue, serous cells of the tracheobronchial submucosal glands in cats, and type II pneumocytes in ferrets [17-19].

Recent reports and articles about the coronavirus disease 2019 (COVID-19) pandemic have established that this disease is caused by SARS-CoV-2, which uses ACE2 receptors in the respiratory system [20-22]. Significantly, a structural analysis recognized residues in SARS-CoV-2 that is essential for ACE2 binding [23]. The entry point of SARS-CoV-2 into pneumocytes and the epithelium of the bronchus and trachea is the ACE2 receptor; consequently, the spikes in the capsule of the coronavirus bind to ACE2 before causing infection and viremia [24,25].

Several articles have characterized the infection, symptoms, and clinical signs of COVID-19 between children and adults; however, the majority of these studies confirmed that children could be infected with COVID-19, but the clinical signs are less severe than those in adults [26,27].

Correspondingly, researchers reported that the mortality and morbidity of COVID-19 were very low in children and young adults compared with those in adults $[28,29]$. Accordingly, this study hypothesized that in COVID-19, the expression of the ACE2 receptor in the respiratory system would normally increase with the increasing age of the rat. Wistar rats were chosen for this experiment as animal models for more investigations about this disease.

We hypothesized that the age of rats could influence the levels of expression and development of ACE2 in lung tissue. This study aimed to evaluate the ACE2 expression in the lung tissue of rats at different ages, which may provide answers regarding some speculations about COVID-19 infections between different ages of people.

\section{Materials and Methods}

\section{Ethical approval}

The Animals and Ethics Committee of the University of Kufa approved to the study to collect samples from rats (Approval no. 1192).

\section{Study period and location}

This study was conducted from $10^{\text {th }}$ November 2020 to $1^{\text {st }}$ July 2021 in the Laboratory of College of Veterinary Medicine, University of Al-Qadisiyah.

\section{Samples}

Eighteen male Wistar rats were obtained from the Animal House of the Faculty of Veterinary Medicine, University of Qadisiyah, and were divided into three groups according to age. The healthy rats were chosen for this study to avoid any physiological or biological changes in the organs and tissue of rats. The first group was 2 weeks, the second group was 2 months, and the third group was 6-8 months.

Rats were anesthetized before being killed by chloroform through the artificial inspiration for $2 \mathrm{~min}$. Animals were killed, and samples of lung tissue were collected for each group. The samples were divided into two group samples, the first group samples were stored in $10 \%$ neutral buffered formalin (NBF) for histology study and second group samples were stored in AccuZol $^{\mathrm{TM}}$ Total RNA Extraction Reagent (Bioneer, Korea) for real-time quantitative polymerase chain reaction (RT-qPCR).

\section{Extraction method of RNA}

The mRNA of tissue was extracted using the AccuZol ${ }^{\circledR}$ reagent kit (Bioneer) according to the manufacturer's instructions. Briefly, $200 \mathrm{mg}$ of tissue was weighed and placed in a $1.5 \mathrm{~mL}$ Eppendorf Tube, and $1 \mathrm{~mL}$ ofAccuZol reagent (Bioneer) was added. Subsequently, $200 \mu \mathrm{L}$ of chloroform (ChemLab, Belgium) was added to each tube and shaken robustly for 15 seconds. Then, the mixture was incubated on ice for $5 \mathrm{~min}$ and centrifuged (Thermo Fisher Scientific, Germany) at $14,000 \times \mathrm{g}$ at $4^{\circ} \mathrm{C}$ for $15 \mathrm{~min}$. The pellets were neglected, and the supernatant was removed in the Eppendorf tube (Abdos LabTech, India) and added with $500 \mu \mathrm{L}$ of isopropanol. Then, the mixture was mixed by inverting the tube 4-5 times and incubated at $4^{\circ} \mathrm{C}$ for $10 \mathrm{~min}$. The samples were centrifuged at $14,000 \times \mathrm{g}$ at $4^{\circ} \mathrm{C}$ for $10 \mathrm{~min}$. The supernatant was poured off, added $1 \mathrm{~mL}$ of $80 \%$ ethanol, and mixed again using a vortex. Subsequently, the samples were recentrifuged at $14,000 \times \mathrm{g}$ at $4^{\circ} \mathrm{C}$ for $10 \mathrm{~min}$. The supernatant was neglected, and the RNA pellet yield was exposed to air for drying. Finally, the RNA pellets were loaded with $50 \mu \mathrm{L}$ of diethylpyrocarbonate water (Bioneer) to each sample to dissolve them; then, these were stored in a freezer at $-20^{\circ} \mathrm{C}$. A NanoDrop spectrophotometer (Thermo Fisher Scientific, USA) was used to evaluate the RNA concentration.

\section{DNase I treatment and cDNA synthesis}

The samples were treated with DNase I enzyme to digest the DNA and extract the RNA using the DNase I enzyme kit (Promega Corporation, USA) according to the manufacturer's instructions. Then, cDNA from the extracted RNA was synthesized using the AccuPower ${ }^{\circledR}$ RocktScript RT PreMix kit according to the manufacturer's instructions. The RNA was translated into cDNA in a thermocycler (Bio-Rad, USA) under the following conditions: cDNA synthesis (RT step) was conducted at $50^{\circ} \mathrm{C}$ for $1 \mathrm{~h}$, and heat inactivation was conducted at $95^{\circ} \mathrm{C}$ for $5 \mathrm{~min}$.

\section{RT-qPCR}

RT-qPCR was conducted to determine the levels of the quantification of the eosinophil cationic protein mRNA transcript, and the RT-qPCR system (Bio-Rad Laboratories Inc., USA) was used to assess the RT-qPCR reactions for the ACE2 target gene. The SYBR Green qPCR Master Mix was applied to determine the amplification of the ACE2 gene expression and glyceraldehyde-3-phosphate dehydrogenase (GAPDH) housekeeping gene for the normalization of gene expression. Primers were designed using 
Table-1: This table showed the RT-qPCR primers with their sequence.

\begin{tabular}{|c|c|c|c|c|}
\hline \multirow{2}{*}{$\frac{\text { Primer }}{\text { ACE2 }}$} & \multicolumn{2}{|c|}{ Sequence $\left(5^{\prime}-3^{\prime}\right)$} & \multirow{2}{*}{$\frac{\text { Amplicon size }}{147 \mathrm{bp}}$} & \multirow{2}{*}{$\begin{array}{l}\text { GenBank accession no. } \\
\text { NM_001012006.1 }\end{array}$} \\
\hline & $\mathrm{F}$ & GCCGTTGGAGAAATCATGTCAC & & \\
\hline & $\mathrm{R}$ & TGGCAGCGTTCCAACAATTG & & \\
\hline \multirow[t]{2}{*}{ GAPDH } & $\mathrm{F}$ & ATGCCCCCATGTTTGTGATG & $136 \mathrm{bp}$ & NM_001012006.1 \\
\hline & $\mathrm{R}$ & TCCACGATGCCAAAGTTGTC & & \\
\hline
\end{tabular}

$\mathrm{RT}$ - $\mathrm{qPCR}=$ Real-time quantitative polymerase chain reaction, $\mathrm{ACE} 2=$ Angiotensin-converting enzyme 2 , GAPDH=Glyceraldehyde-3-phosphate dehydrogenase

the Primer3Plus (Table-1 lists the primer sequences, which were made by Scientific Researcher Co. Ltd., Iraq).

The qPCR Master Mix was prepared for the specific target gene and the GAPDH housekeeping gene according to the manufacturer's instructions (AccuPower ${ }^{\circledR}$ 2XGreen Star qPCR Master Mix kit; Bioneer). Furthermore, the thermocycler conditions were applied according to Table-2. The gene expression target was analyzed using the $2-\Delta \Delta \mathrm{CT}$ Livak method [30].

\section{Histological process of tissue}

Tissue specimens were fixed in $10 \%$ formalin (NBF) and washed with tap water for $2 \mathrm{~h}$; subsequently, these specimens underwent a series of ethyl alcohol washes and then with xylene (twice) for $2 \mathrm{~min}$ for each wash. Next, tissues were embedded in paraffin, and tissue sections were prepared. Paraffin was removed by xylene and rehydrated, and sections were stained using routine hematoxylin and eosin stains. The sections were examined under light microscopy (Olympus, Japan), and digital images were obtained for each section using $10 \times$ [31].

\section{Statistical analysis}

The RT-qPCR raw data were analyzed using Excel 2019 (Microsoft, USA). The means and standard errors of the gene for three groups were determined, and the ACE2 expression in different ages was assessed using one-way single-factor analysis of variance.

\section{Results}

In this study, three groups of rats according to age (first group, 2 weeks; second group, 2 months; and third group, 6-8 months) were used to determine the levels of expression of ACE2 in the lung tissue. The fresh samples were used for histology and RT-qPCR study. Subsequently, the anatomical inspection showed that the right lung was divided into four lobes and the left lung had one lobe and was undivided. Histologically, the lung was enclosed by a single layer of squamous epithelial cells overlying connective tissue (visceral pleura). The lung parenchyma showed bronchioles of different sizes and shapes (terminal and respiratory bronchioles). The epithelium lining of the bronchiole gradients was changed from pseudostratified columnar to simple columnar. The respiratory bronchioles are also divided into alveolar ducts, which lead to the alveolar sacs and alveoli (Figure-1).
Table-2: This table shows the RT-qPCR thermocycler conditions.

\begin{tabular}{lccc}
\hline RT-qPCR step & Temperature & Time & $\begin{array}{c}\text { Repeat } \\
\text { cycle }\end{array}$ \\
\hline CDNA Step & $50^{\circ} \mathrm{C}$ & 1 hour & 1 \\
Denaturation & $95^{\circ} \mathrm{C}$ & $20 \mathrm{sec}$ & 45 \\
Annealing $\backslash$ Extension & $60^{\circ} \mathrm{C}$ & $30 \mathrm{sec}$ & \\
$\begin{array}{l}\text { Detection(scan) } \\
\text { Melting }\end{array}$ & $60-95^{\circ} \mathrm{C}$ & $0.5 \mathrm{sec}$ & 1 \\
\hline
\end{tabular}

The RT-qPCR amplification plots of ACE2 gene of the lung tissue were precisely observable threshold cycles $(\mathrm{Ct})$ numbers of expression which were different between groups of rats according to the age at 2 weeks, 2 months, and 6-8 months (range, $\mathrm{C}_{\mathrm{T}} 30.2-\mathrm{C}_{\mathrm{T}}$ 32.59, $\mathrm{C}_{\mathrm{T}}$ 29.36- $\mathrm{C}_{\mathrm{T}}$ 30.81, and $\mathrm{C}_{\mathrm{T}}$ 28.17- $\mathrm{C}_{\mathrm{T}}$ 29.56, respectively (Figure-2).

The specificity of RT-qPCR primer was tested by melting peak analysis which was shown a highly specific without any non-specific products amplification; moreover, all experimental specimens had a melting peak ranging from $79^{\circ} \mathrm{C}$ to $80^{\circ} \mathrm{C}$ (Figures-2 and 3). The RT-qPCR efficiency was assessed using the cDNA standard curve for experimental samples and was shown to be $108 \%$ (Figure-4).

Our findings showed that the ACE2 expression was significantly different between groups of rats depending on their age. The RT-qPCR results showed that the older animal group (age of 6-8 months) had a significantly higher expression of ACE2 than the other animal groups (ages of 2 weeks and 2 months). In the same way, the second group (age of 2 months) had a significantly higher expression of ACE2 than the first group (age of 2 weeks) (Table-3 and Figures-5 and 6).

These findings confirmed that the expression of ACE2 in the lung tissue would be different depending on the age of animals. For this reason, it seemed that immature animals would be less infected with COVID-19 compared with mature ones.

\section{Discussion}

The ACE2 is a cellular transmembrane glycoprotein and has an extensive homolog to carboxypeptidase ACE. Moreover, it ends with non-catalytic extracellular and cytosolic domains, but lacks active dipeptidyl carboxypeptidase catalytic domains [32-34].

Several researchers described that ACE2 is found in various cells and tissues in rodents, with high expression in the heart, lymphoid tissues, and digestive and respiratory systems and low expression in the 


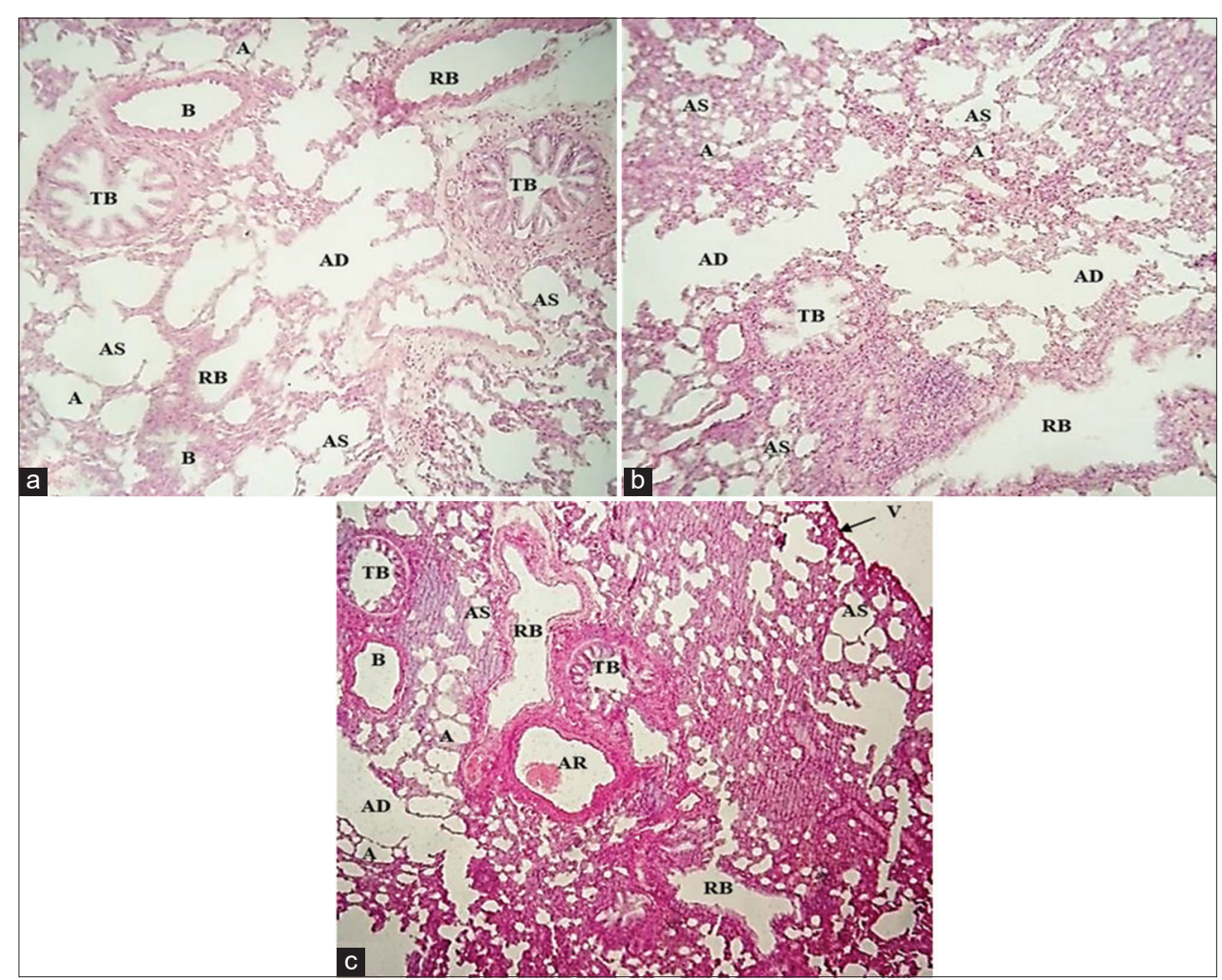

Figure-1: These images illustrated the histological structure of the lung tissue of rats for different groups. Indicator (a) is a first group and age (2 weeks), (b) is a second group and age (2 months), and (c) is a third group and age (6-8 months). $\mathrm{AS}=$ Alveolar sac, $\mathrm{B}=$ Bronchioles, $\mathrm{TB}=$ Terminal bronchiole, $\mathrm{RB}=$ Respiratory bronchiole, $\mathrm{AD}=\mathrm{Alveolar}$ duct, $\mathrm{A}=\mathrm{Alveoli}$, $A R=$ Artery, $V=$ Visceral pleura $(H$ and $E$, staining $100 \times)$.

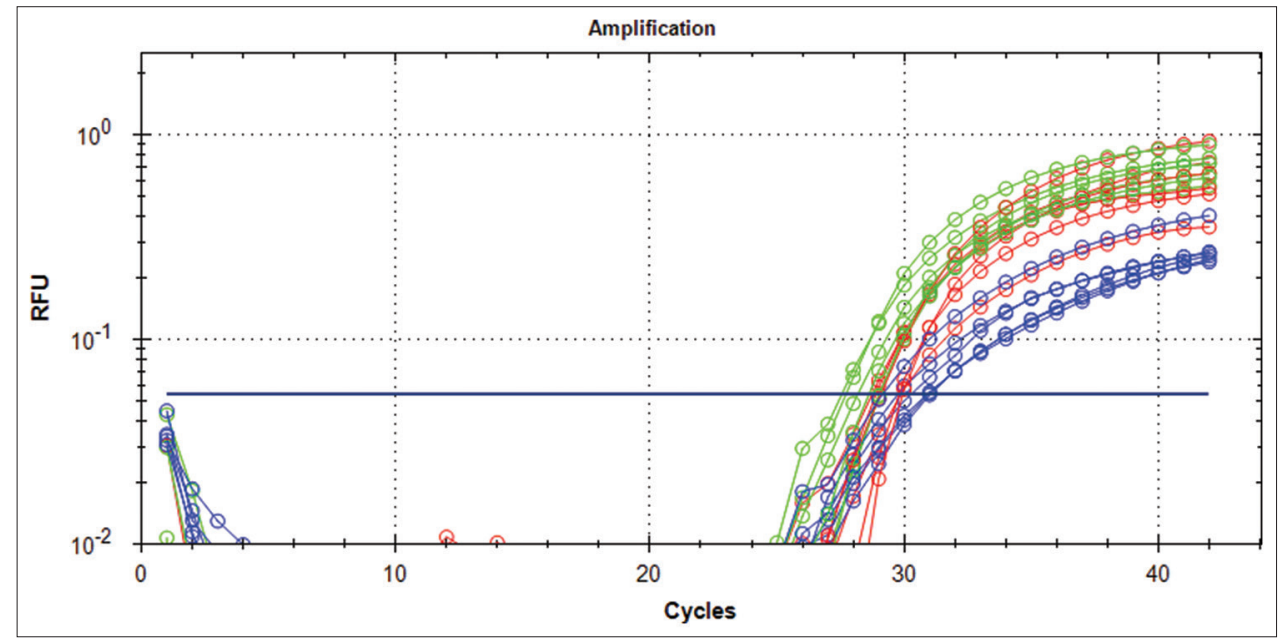

Figure-2: This figure presented the RT-qPCR amplification plots of the angiotensin-converting enzyme-2 gene of the lung tissue of rats for different groups. The blue plots (first group), the red plots (second group), and the green plots (third group).

central nervous system [35-38]. Our results confirmed that ACE2 is expressed in the lung tissue of rats. ACE2 has synchronized physiological and biological functions between cells; therefore, its expression levels would allow for homeostatic regulation of circulating angiotensin II. It is attached to the cell membrane in endothelial cells and lung tissue and could be shed from the cell surface and regulate other physiological functions $[39,40]$. This study determined the expression of the ACE2 in the lung tissue, which regulates the function of epithelial cells and pneumocytes.
Our study determined that the transcriptome expression of ACE2 was dependent on the age of rats and there were differences between mature and immature ones. Other researchers have confirmed that the ACE2 receptor is considered the entry point of important viruses, such as SARS-CoV and SARSCoV-2 [41-44]. Therefore, the pathogenesis of an infection could be determined depending on the expression of ACE2.

Many studies have indicated that SARS-CoV and SARS-CoV-2 infect adults and elderly people more than 
Available at www.veterinaryworld.org/Vol.15/February-2022/25.pdf

Table-3: This table displayed values of gene expression and housekeeping gene which were analyzed using 2- $\Delta \Delta \mathrm{CT}$ Livak method. ACE2=Angiotensin-converting enzyme 2 .

\begin{tabular}{|c|c|c|c|c|c|c|c|}
\hline $\begin{array}{l}\text { Experimental } \\
\text { groups }\end{array}$ & $\begin{array}{l}\text { CT } \\
\text { ACE2 }\end{array}$ & $\begin{array}{c}\text { CT } \\
\text { GAPDH }\end{array}$ & ACT test & $\begin{array}{c}\Delta C T \\
\text { control }\end{array}$ & $\begin{array}{l}\Delta \Delta C T \\
\text { control }\end{array}$ & $\begin{array}{l}\text { Fold change } \\
\left(2^{\wedge} \Delta C T\right)\end{array}$ & $\begin{array}{l}\text { Mean and St. error } \\
\text { for Exp. groups }\end{array}$ \\
\hline A & 31.77 & 25.39 & 6.38 & 7.37 & -0.99 & 1.986 & $1.297 \pm 0.38$ \\
\hline A & 32.52 & 24.96 & 7.56 & 7.37 & 0.19 & 0.877 & \\
\hline$A$ & 30.2 & 24.29 & 5.91 & 7.37 & -1.46 & 2.751 & \\
\hline A & 32.59 & 23.26 & 9.33 & 7.37 & 1.96 & 0.257 & \\
\hline A & 32.52 & 25.50 & 7.02 & 7.37 & -0.35 & 1.275 & \\
\hline$A$ & 31.16 & 23.14 & 8.02 & 7.37 & 0.65 & 0.637 & \\
\hline B & 29.36 & 24.20 & 5.16 & 7.37 & -2.21 & 4.627 & $3.947 \pm 0.57$ \\
\hline B & 30.81 & 24.53 & 6.28 & 7.37 & -1.09 & 2.129 & \\
\hline B & 30.39 & 24.65 & 5.74 & 7.37 & -1.63 & 3.095 & \\
\hline B & 29.59 & 24.45 & 5.14 & 7.37 & -2.23 & 4.691 & \\
\hline B & 30.3 & 24.59 & 5.71 & 7.37 & -1.66 & 3.160 & \\
\hline B & 29.42 & 24.63 & 4.79 & 7.37 & -2.58 & 5.979 & \\
\hline C & 28.8 & 24.12 & 4.68 & 7.37 & -2.69 & 6.453 & $5.616 \pm 0.74$ \\
\hline C & 28.17 & 22.55 & 5.62 & 7.37 & -1.75 & 3.364 & \\
\hline C & 29.18 & 24.60 & 4.58 & 7.37 & -2.79 & 6.916 & \\
\hline C & 28.24 & 23.73 & 4.51 & 7.37 & -2.86 & 7.260 & \\
\hline C & 29.51 & 23.84 & 5.67 & 7.37 & -1.70 & 3.249 & \\
\hline C & 29.56 & 24.88 & 4.68 & 7.37 & -2.69 & 6.453 & \\
\hline Mean A & 31.79 & 24.42 & 7.37 & & & & \\
\hline
\end{tabular}

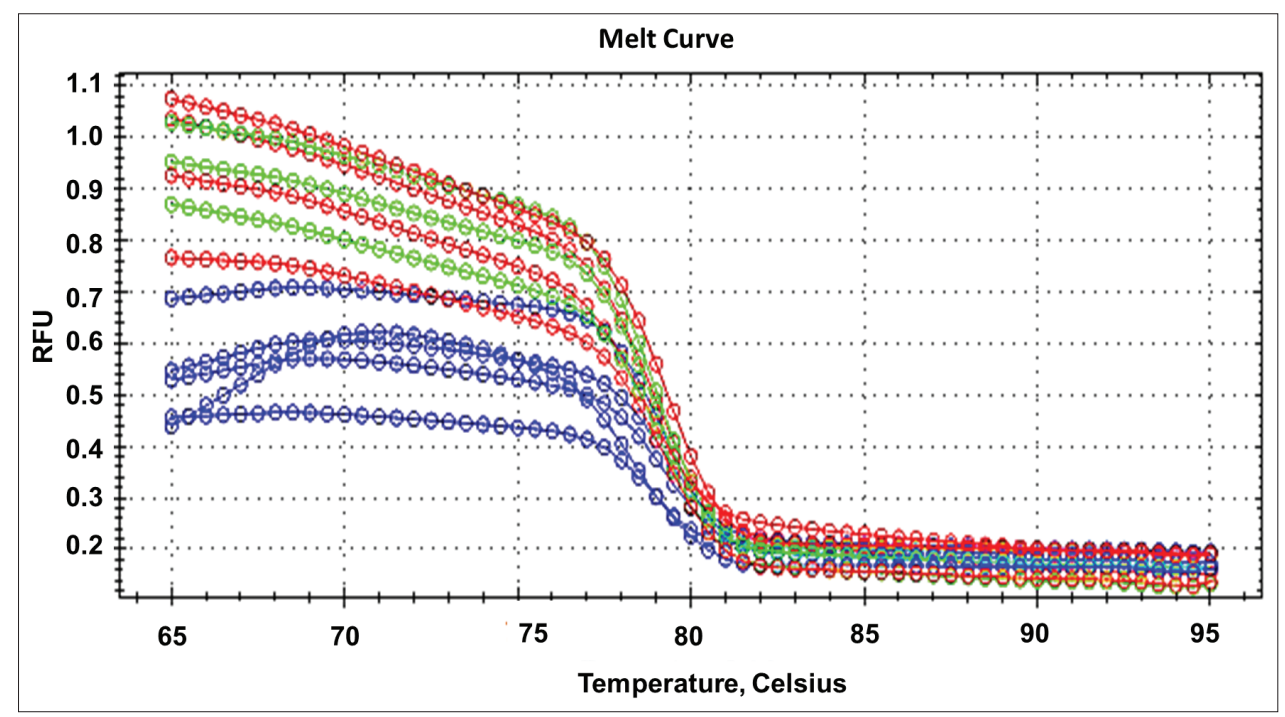

Figure-3: This figure displayed the RT-qPCR melting curve of the angiotensin-converting enzyme-2 gene of the lung tissue of rats for different groups. The blue plots (first group), the red plots (second group), and the green plots (third group).

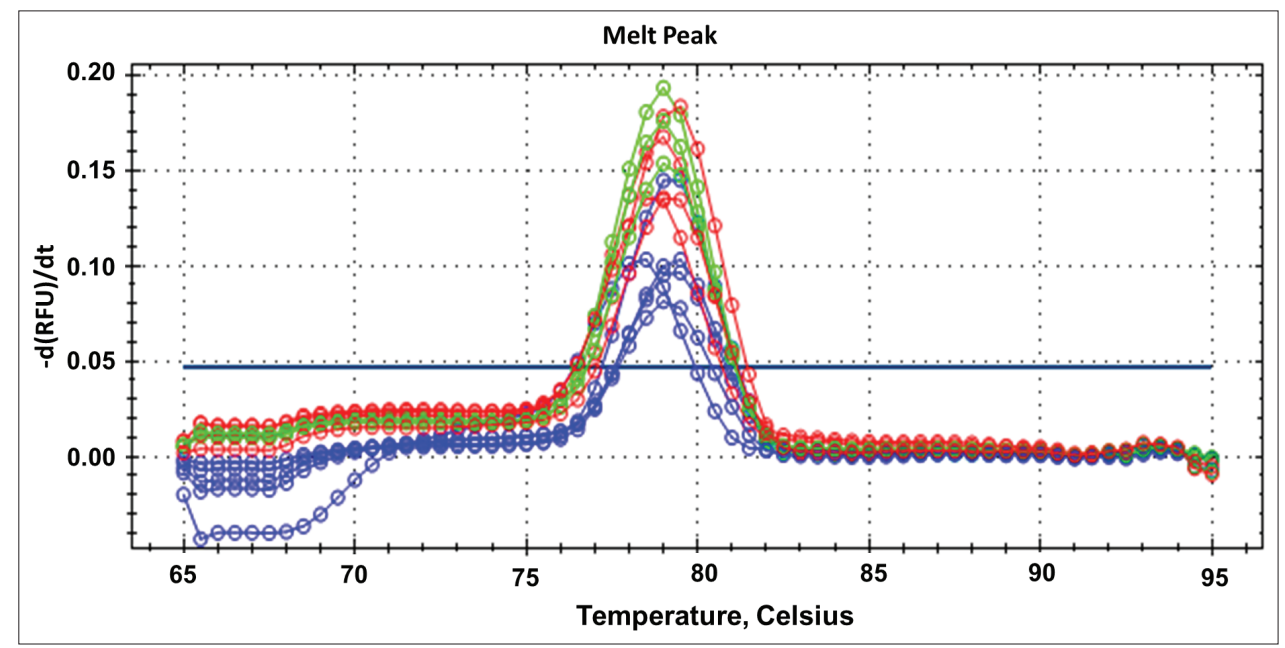

Figure-4: This figure exhibited RT-qPCR melting peak of the angiotensin-converting enzyme-2 gene for the rat lung tissue of experimental groups. The blue plots (First group), the red plots (second group), and the green plots (third group) showed that RT-qPCR melting temperature was $79-80^{\circ} \mathrm{C}$. 


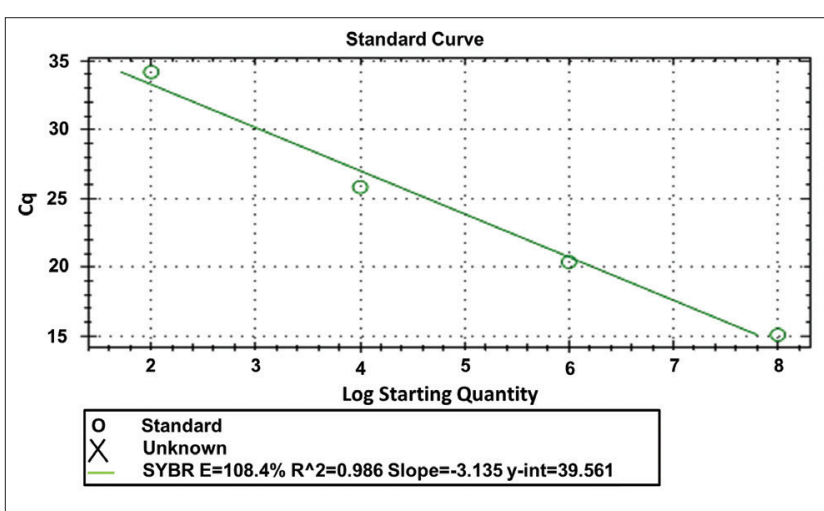

Figure-5: This figure displayed the RT-qPCR standard curve of angiotensin-converting enzyme-2 gene for the rat lung tissue of experimental groups and showed that RT-qPCR efficiency was $108 \%$.

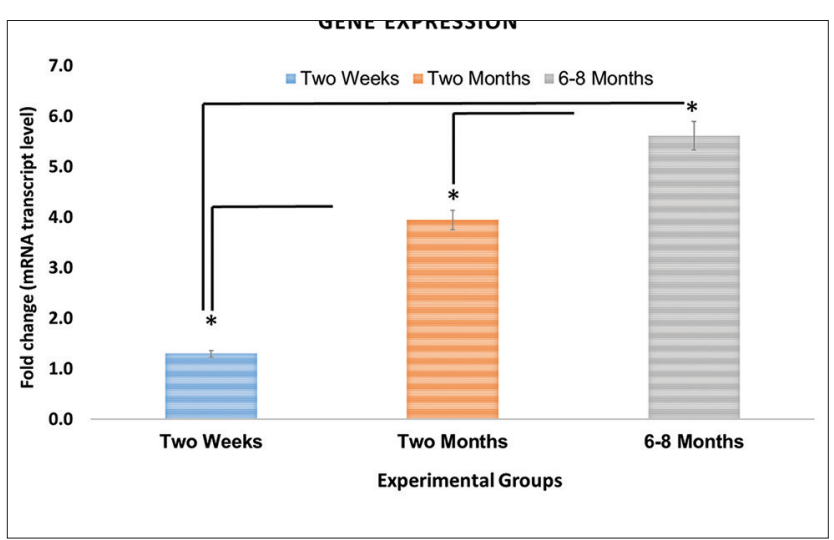

Figure-6: This histogram showed the comparison of the total gene expression between groups. Graph showing total expression of angiotensin-converting enzyme-2 that expressed in lung tissue of rats at a different stage of the age. Each column represents the group and age of the rats. Three groups $(p=0.05)$ displayed significantly higher between groups. *Indicates significant values derived using analysis of variance (single factor).

children; thus, the clinical signs are less severe than those in adults [45-48]. Taken together, these previous studies are in agreement with our results, which confirmed that the level of expression of ACE is significantly higher in mature rats than in immature rats and younger.

The high level of expression of ACE2 in the respiratory system may be used to predict the occurrence of COVID-19 infection and the prognosis of individuals infected with the virus. Moreover, the age of people would be restricted the distribution and expression of ACE2 receptor tissue in the respiratory system, which is being the entry point of the virus; thus, the level of the receptor would be influenced by the prognosis's COVID-19 and detected the severity of infection, mortality, and morbidity $[49,50]$. Therefore, these studies and our results confirmed that the expression of ACE2 is different between ages and other factors. For these reasons, SARS-CoV-2 infection would also be different between people.

The level of expression of ACE2 would determine the severity of SARS-CoV-2 infections after exposure to the virus [51,52], which could be expected the severe clinical signs of infected people, and percentage of morbidity and mortality. Overall, this result explained that the age of rats would influence the expression levels of ACE2 in lung tissue, which may predict the type of infection, that is, COVID-19 and SARS-CoV infections.

\section{Conclusion}

This study shows that the ACE2 receptors in the lung tissue are differentially expressed according to the age of rats; therefore, the age of rats affects the expression levels of ACE2. This result may provide some clarifications regarding the coronavirus infection and other infectious diseases concerning receptors in the respiratory system. Moreover, the severity of the coronavirus disease would be determined depending on the expression of ACE2 in the respiratory system; therefore, more studies should be focused on these receptors in the upper and lower respiratory system.

\section{Authors' Contributions}

HA: Designed the experiment and reviewed the manuscript. HHN: Conducted the study, performed the experimental laboratory work, and revised the manuscript. HA: Data analysis, project advisor, and reviewed the manuscript. NAMA: Conducted the literature review, interpreted the data, and drafted the manuscript. All authors have revised and approved the final manuscript.

\section{Acknowledgments}

This work was funded and supported by the Faculty of Veterinary Medicine/University of Kufa and College of Veterinary Medicine/the University of Qadisiyah (Grant No.361). Furthermore, we appreciate the collaboration of technician staff in the College of Veterinary Medicine, University of Qadisiyah.

\section{Competing Interests} interests.

The authors declare that they have no competing

\section{Publisher's Note}

Veterinary World remains neutral with regard to jurisdictional claims in published institutional affiliation.

\section{References}

1. Li, M.Y., Li, L., Zhang, Y. and Wang, X.S. (2020) Expression of the SARS-CoV-2 cell receptor gene ACE2 in a wide variety of human tissues. Infect. Dis. Poverty, 9(1): 45.

2. Hikmet, F., Méar, L., Edvinsson, A., Micke, P., Uhlén, M. and Lindskog, C. (2020) The protein expression profile of ACE2 in human tissues. Mol. Syst. Biol., 16(7): e9610.

3. Camargo, S.M., Singer, D., Makrides, V., Huggel, K., Pos, K.M., Wagner, C.A., Kuba, K., Danilczyk, U., Skovby, F., Kleta, R., Penninger, J.M. and Verrey, F. (2009) Tissue-specific amino acid transporter partners ACE2 and collectrin differentially interact with hartnup mutations. Gastroenterology, 136(3): 872-882.

4. Keidar, S., Kaplan, M. and Gamliel-Lazarovich, A. (2007) 
ACE2 of the heart: From angiotensin I to angiotensin (1-7). Card. Vasc. Res., 73(3): 463-469.

5. Imai, Y., Kuba, K., Rao, S., Huan, Y., Guo, F., Guan, B., Yang, P., Sarao, R., Wada, T., Leong-Poi, H., Crackower, M.A., Fukamizu, A., Hui, C.C., Hein, L., Uhlig, S., Slutsky, A.S., Jiang, C. and Penninger, J.M. (2005) Angiotensin-converting enzyme 2 protects from severe acute lung failure. Nature, 436(7047): 112-116.

6. Tikellis, C. and Thomas, M. (2012) Angiotensin-converting enzyme 2 (ACE2) is a key modulator of the renin-angiotensin system in health and disease. Int. J. Pept., 2012: 256294.

7. Tipnis, S.R., Hooper, N.M., Hyde, R, Karran, E., Christie, G. and Turner, A.J. (2000) A human homolog of angiotensin-converting enzyme: Cloning and functional expression as a captopril-insensitive carboxypeptidase. J. Bio. Chem., 275(43): 33238-33243.

8. Warner, F., Smith, A.I., Hooper, N.M. and Turner, A.J. (2004) Angiotensin-converting enzyme-2: A molecular and cellular perspective. Cell. Mol. Life Sci., 61(21): 2704-2713.

9. Santos, R., Ferreira, A.J., Verano-Braga, T. and Bader, M. (2013) Angiotensin-converting enzyme 2, angiotensin-(1-7) and Mas: New players of the renin-angiotensin system. $J$. Endocrinol., 216(2): R1-R17.

10. Burrell, L.M., Johnston, C.I., Tikellis, C. and Cooper, M.E. (2004) ACE2, a new regulator of the renin-angiotensin system. Trends. Endocrinol. Metab., 15(4): 166-169.

11. Imai, Y., Kuba, K., Ohto-Nakanishi, T. and Penninger, J.M. (2010) Angiotensin-converting enzyme 2 (ACE2) in disease pathogenesis. Circ. J., 74(3): 405-410.

12. Wong, D.W., Oudit, G.Y., Reich, H., Kassiri, Z., Zhou, J., Liu, Q.C., Backx, P.H., Penninger, J.M., Herzenberg, A.M. and Scholey, J.W. (2007) Loss of angiotensin-converting enzyme-2 (Ace2) accelerates diabetic kidney injury. Am. J. Pathol., 171(2): 438-451.

13. Williams, V.R. and Scholey, J.W. (2018) Angiotensinconverting enzyme 2 and renal disease. Curr. Opin. Nephrol. Hypertens., 27(1): 35-41.

14. Chappel, M. and Ferrario, C. (2006) ACE and ACE2: Their role to balance the expression of angiotensin II and angiotensin-(1-7). Kidney Int., 70(1): 8-10.

15. Ingelfinger, J.R. (2009) Angiotensin-converting enzyme 2: Implications for blood pressure and kidney disease. Curr. Opin. Nephrol. Hypertens., 18(1): 79-84.

16. Prada, J.A.H., Ferreira, A.J., Katovich, M.J., Shenoy, V., Qi, Y., Santos, R.A.S., Castellano, R.K., Lampkins, A.J., Gubala, V., Ostrov, D.A. and Raizada, M.K. (2008) Structure-based identification of small-molecule angiotensin-converting enzyme 2 activators as novel antihypertensive agents. Hypertension, 51(5): 1312-1317.

17. Van den Brand, J., Haagmans, B.L., Leijten, L, van Riel, D., Martina, B.E.E., Osterhaus, A.D.M. and Kuiken, T. (2008) Pathology of experimental SARS coronavirus infection in cats and ferrets. Vet. Pathol., 45(4): 551-562.

18. Hamming, I., Timens, W., Bulthuis, M.L.C., Lely, A.T., Navis, G.J. and van Goor, H. (2004) Tissue distribution of ACE2 protein, the functional receptor for SARS coronavirus. A first step in understanding SARS pathogenesis. $J$. Pathol., 203(2): 631-637.

19. Zuo, W., Zhao, X. and Chen, Y.G. (2010) SARS Coronavirus and Lung Fibrosis, in Molecular Biology of the SARSCoronavirus. Springer, Berlin. p247-258.

20. Shang, J., Ye, G., Shi, K., Wan, Y., Luo, C., Aihara, H. Geng, Q., Auerbach, A. and Li, F. (2020) Structural basis of receptor recognition by SARS-CoV-2. Nature, 581(7807): 221-224.

21. Chen, J., Jiang, Q., Xia, X., Liu, K., Yu, Z., Tao, W., Gong, W. and Han, J.D.J. (2020) Individual variation of the SARSCoV-2 receptor ACE2 gene expression and regulation. Aging. Cell, 19(7): e13168.

22. Lan, J., Ge, J., Yu, J., Shan, S., Zhou, H., Fan, S., Zhang, Q., Shi, X., Wang, Q., Zhang, L. and Wang, X. (2020) Structure of the SARS-CoV-2 spike receptor-binding domain bound to the ACE2 receptor. Nature, 581(7807): 215-220.

23. Hussain, M., Jabeen, N., Raza, F., Shabbir, S., Baig, A.A., Amanullah, A. and Aziz, B. (2020) Structural variations in human ACE2 may influence its binding with SARS-CoV-2 spike protein. J. Med. Virol., 92(9): 1580-1586.

24. Cuervo, N.Z. and Grandvaux, N. (2020) ACE2: Evidence of role as an entry receptor for SARS-CoV-2 and implications in comorbidities. Elife, 9: e61390.

25. Mariappan, V. and Pillai, A.B. (2020) Angiotensinconverting enzyme 2: A protective factor in regulating disease virulence of SARS-COV-2. IUBMB Life, 72(12): 2533-2545

26. Mallineni, S.K., Innes, N.P., Raggio, D.P., Araujo, M.P., Robertson, M.D. and Jayaraman, J. (2020) Coronavirus disease (COVID-19): Characteristics in children and considerations for dentists providing their care. Int. J. Paediatr. Dent. 30(3): 245-250.

27. Balasubramanian, S., Rao, N.M., Goenka, A., Roderick, M. and Ramanan, A.V. (2020) Coronavirus disease 2019 (COVID-19) in children-what we know so far and what we do not. Indian Pediatr., 57(5): 435-442.

28. Liguoro, I., Pilotto, C., Bonanni, M., Ferrari, M.E., Pusiol, A., Nocerino, A., Vidal, E. and Cogo, P. (2020) SARS-COV-2 infection in children and newborns: A systematic review. Eur. J. Pediatr., 179(7): 1029-1046.

29. Ayoub, H.H., Chemaitelly, H., Seedat, S., Mumtaz, G.R., Makhoul, M. and Abu-Raddad, L.J. (2020) Age could be a driving variable SARS-CoV-2 epidemic trajectories worldwide. PLoS One, 15(8): e0237959.

30. Livak, K.J. and Schmittgen, T.D. (2001) Analysis of relative gene expression data using real-time quantitative PCR and the 2(-Delta Delta C(T)) method. Methods, 25(4): 402-408.

31. Suvarna, S. and Layton, C. (2013) Bancroft's Theory and Practice of Histological Techniques. $7^{\text {th }}$ ed. Churchill Livingstone Elsevier, London, United Kingdom

32. Zhang, H., Wada, J., Hida, K., Tsuchiyama, Y., Hiragushi, K., Shikata, K., Wang, H., Lin, S., Kanwar, Y.S. and Makino, H. (2001) Collectrin, a collecting duct-specific transmembrane glycoprotein, is a novel homolog of ACE2 and is developmentally regulated in embryonic kidneys. J. Biol. Chem., 276(20): 17132-17139.

33. Warner, F.J., Lew, R.A., Smith, A.I., Lambert, D.W., Hooper, N.M. and Turner, A.J. (2005) Angiotensinconverting enzyme 2 (ACE2), but not ACE, is preferentially localized to the apical surface of polarized kidney cells. $J$. Biol. Chem., 280(47): 39353-39362.

34. Singer, D. and Camargo, S.M. (2011) Collectrin and ACE2 in renal and intestinal amino acid transport. Channels, 5(5): 410-423.

35. Gembardt, F., Sterner-Kock, A., Imboden, H., Spalteholz, M., Reibitz, F., Schultheiss, H.P., Siems, W.E. and Walther, T. (2005) Organ-specific distribution of ACE2 mRNA and correlating peptidase activity in rodents. Peptides, 26(7): 1270-1277.

36. Harmer, D., Gilbert, M., Borman, R. and Clark, K.L. (2002) Quantitative mRNA expression profiling of ACE 2, a novel homologue of angiotensin-converting enzyme. FEBS Lett., 532(1-2): 107-110.

37. Gallagher, P.E., Chappell, M.C., Ferrario, C.M. and Tallant, E.A. (2006) Distinct roles for ANG II and ANG-(1-7) in the regulation of angiotensin-converting enzyme 2 in rat astrocytes. Am. J. Physiol. Cell Physiol., 290(2): C420-C42.

38. Shenoy, V., Ferreira, A.J., Qi, Y., Fraga-Silva, R.A., DíezFreire, C., Dooies, A., Jun, J.Y., Sriramula, S., Mariappan, N., Pourang, D., Venugopal, C.S., Francis, J., Reudelhuber, T., Santos, R.A., Patel, J.M., Raizada, M.K. and Katovich, M.J. (2010) The angiotensin-converting enzyme 2/angiogenesis-(1-7)/Mas axis confers cardiopulmonary protection against lung fibrosis and pulmonary hypertension. Am. J. Respir. Crit. Care Med., 182(8): 1065-1072.

39. Turner, A.J. (2015) ACE2 cell biology, regulation, and physiological functions. The Protective Arm of the 
Renin-Angiotensin System (RAS). Elsevier, Netherlands, p185.

40. Li, G., He, X., Zhang, L., Ran, Q., Wang, J., Xiong, A., Wu, D., Chen, F., Sun, J. and Chang, C. (2020) Assessing ACE2 expression patterns in lung tissues in the pathogenesis of COVID-19. J. Autoimmun., 112: 102463.

41. Klingenstein, M., Klingenstein, S., Neckel, P.H., Mack, A.F., Wagner, A.P., Kleger, A., Liebau, S. and Milazzo, A. (2020) Evidence of SARS-CoV2 entry protein ACE2 in the human nose and olfactory bulb. Cells Tissues Organs, 209(4-6): 155-164.

42. Chen, M., Shen, W., Rowan, N.R., Kulaga, H., Hillel A., Ramanathan, M. Jr. and Lane, A.P. (2020) Elevated ACE-2 expression in the olfactory neuroepithelium: implications for anosmia and upper respiratory SARS-CoV-2 entry and replication. Eur. Respir. J., 56(3): 2001948.

43. Majdic, G. (2020) Could sex/gender differences in ACE2 expression in the lungs contribute to the large gender disparity in the morbidity and mortality of patients infected with the SARS-CoV-2 virus? Front. Cell Infect. Microbiol., 10: 327 .

44. Jain, A. (2020) COVID-19 and lung pathology. Indian J. Pathol. Microbiol., 63(2): 171-172.

45. Dhochak, N., Singhal, T., Kabra, S.K. and Lodha, R. (2020) Pathophysiology of COVID-19: why children fare better than adults? Ind. J. Pediatr., 87(7): 537-546.

46. Ludvigsson, J.F. (2020) Systematic review of COVID-19 in children shows milder cases and a better prognosis than adults. Acta Paediatr., 109(6): 1088-1095.
47. Zheng, F., Liao, C., Fan, Q.H., Chen, H.B., Zhao, X.G., Xie, Z.G., Li, X.L., Chen, C.X., Lu, X.X., Liu, Z.S., Lu, W., Chen, C.B., Jiao, R., Zhang, A.M., Wang, J.T., Ding, X.W., Zeng, Y.G., Cheng, L.P., Huang, Q.F., Wu, J., Luo, X.C., Wang, Z.J., Zhong, Y.Y., Bai, Y., Wu, X.Y. and Jin, R.M. (2020) Clinical characteristics of children with coronavirus disease 2019 in Hubei, China. Curr. Med. Sci., 40(2): 275-280.

48. Ding, Y., Yan, H. and Guo, W. (2020) Clinical characteristics of children with COVID-19: A meta-analysis. Front. Pediatr., 3(8): 431.

49. Bastolla, U. (2020) The differential expression of the ACE2 receptor across ages and gender explains the differential lethality of SARS-Cov-2 and suggests possible therapy. arXiv, 2020(V2): 200407224.

50. Yee, M., Cohen, E.D., Haak, J., Dylag, A.M. and O'Reilly, M.A. (2020) Neonatal hyperoxia enhances age-dependent expression of SARS-CoV-2 receptors in mice. bioRxiv, 10(1):1-4.

51. Maggi, F., Rosellini, A., Spezia, P.G., Focosi, D., Macera, L., Lai, M., Pistello, M., de Iure, A., Tomino, C., Bonassi, S. and Russo, P. (2021) Nicotine upregulates ACE2 expression and increases competence for SARS-CoV-2 in human pneumocytes. ERJ Open Res., 7(2): 00713-2020.

52. Hashizume, M., Gonzalez, G., Ono, C., Takashima, A. and Iwasaki, M. (2021) Population-specific ACE2 single-nucleotide polymorphisms have limited impact on SARS-CoV-2 infectivity in vitro. Viruses, 13(1): 67. 